\title{
PENGARUH MODEL PEMBELAJARAN COOPERATIVE INTEGRATED READING AND COMPOSITION BERBANTUAN MEDIA GAMBAR TERHADAP KETERAMPILAN MEMBACA INTENSIF
}

\author{
Sang Ayu Made Sintya Dewi ${ }^{1}$, Ni Wayan Arini ${ }^{2}$, Gede Wira Bayu ${ }^{3}$ \\ 1,2,3 Jurusan Pendidikan Guru Sekolah Dasar, FIP \\ Universitas Pendidikan Ganesha \\ Singaraja, Indonesia
}

e-mail: mdsangayu@gmail.com ${ }^{1}$, wynarini@gmail.com $^{2}$, gdewirabayu@gmail.com $^{3}$

\begin{abstract}
Abstrak
Penelitian ini bertujuan untuk meningkatan hasil belajar PPKn melalui penerapan model pembelajaran quantum berbantuan media audio-visual dan puzzle siswa kelas V SD Negeri 3 Banjar Jawa. Jenis penelitian ini adalah penelitian tindakan kelas (PTK) yang dilaksanakan dalam dua siklus. Setiap siklus terdiri dari empat tahap yaitu perencanaan, pelaksanaan, observasi atau evaluasi, dan refleksi. Subjek penelitian ini adalah siswa kelas V C SD Negeri 3 Banjar Jawa yang berjumlah 32 orang terdiri dari 19 orang siswa perempuan dan 13 orang siswa laki-laki. Pengumpulan data dilakukan dengan metode tes yang instrumennya berupa tes objektif. Data hasil belajar PPKn dianalisis menggunakan metode analisis deskriptif kuantitatif. Hasil penelitian menunjukan rata-rata hasil belajar PPKn siswa pada siklus I yaitu 76,6 dengan M\% sebesar 76,6\% berada pada kategori sedang dan berada pada interval $65-79$ dengan kategori sedang. Pada pada siklus II rata-rata hasil belajar PPKn siswa yaitu 88,2 dengan M\% sebesar 88,2\% dan berada pada interval 80 - 89 dengan kategori tinggi. Peningkatan yang terjadi jika dihitung menggunakan rumus $\mathrm{Gn}$ skor yaitu sebesar 0,49 yang jika dikonversikan pada tabel kriteria peningkatan hasil belajar berada pada kategori sedang $(0,30-0,69)$. Dengan demikian dapat disimpulkan bahwa melalui penerapan model pembelajaran quantum berbantuan media audio-visual dan puzzle dapat meningkatkan hasil belajar PPKn siswa kelas V C semester II tahun ajaran 2017/2018 di SD Negeri 3 Banjar Jawa.
\end{abstract}

Kata kunci: hasil belajar PPKn, media audio-visual dan puzzle, model pembelajaran quantum

\section{Abstract}

This study aimed to improve civic learning outcomes through the application of quantum learning model aided audio-visual and puzzle media in class $V$ students of SD Negeri 3 Banjar Jawa. This type of research is a classroom action research (PTK) which was conducted in two cycles. Each cycle consists of four phases: planning, implementation, observation or evaluation, and reflection. This subjects were fifth grade students at SD Negeri 3 Banjar Jawa amounting to 32 people, consisting of 19 female students and 13 male students. Data collected by the instrument test method is objective tests. Data of civic learning outcomes were analyzed using quantitative descriptive analysis method. The results showed the average of civic learning outcomes of students in first cycle is 76,6 with $\mathrm{M} \%$ is $76,6 \%$ are in the medium category and are in the interval 65-79 with medium category. In second cycle, the average of civic learning outcomes of students is 88,2 with $\mathrm{M} \%$ is $88,2 \%$ and are in interval 80-89 with high category. The increases that occur when calculated using Gn score formula is 0,49 which if converted on the table of increase learning outcome criteria are in the medium category $(0,30$ $0,69)$. It can be concluded that through the application of quantum learning model aided audio-visual and puzzle media can improve civic learning outcomes in V C class semester II academic year 2017/2018 in SD Negeri 3 Banjar Jawa.

Keywords: civic learning outcomes, audio-visual and puzzle media, quantum learning model 


\section{Pendahuluan}

Seiring dengan perkembangan ilmu pengetahuan dan teknologi, maka otomatis pola pikir masyarakat berkembang dalam berbagai aspek. Hal ini sangat berpengaruh dalam dunia pendidikan yang menuntut adanya inovasi baru dalam menimbulkan perubahan yang berbeda dari sebelumnya. Tujuan pendidikan di Indonesia diharapkan dapat mempersiapkan peserta didik menjadi warga negara yang memiliki komitmen kuat dan konsisten untuk mempertahankan Negara Kesatuan Republik Indonesia (NKRI). Komitmen yang kuat dan konsisten terhadap prinsip dan semangat kebangsaan dalam kehidupan bermasyarakat, berbangsa dan bernegara berdasar Pancasila dan UUD 1945, perlu ditingkatkan terusmenerus untuk memberikan pemahaman yang mendalam tentang NKRI. Usaha memberikan nilai-nilai luhur kepada generasi baru ini tertuang dalam mata pelajaran di sekolah dasar yaitu dalam mata pelajaran pendidikan kewarganegaraan (PKn).

Susanto (2013:225) menyatakan bahwa "pendidikan kewarganegaraan adalah mata pelajaran yang digunakan sebagai wahana untuk mengembangkan dan melestarikan nilai luhur moral yang berakar pada budaya bangsa Indonesia". Nilai luhur dan moral ini diharapkan dapat diwujudkan dalam bentuk perilaku kehidupan siswa sehari-hari, baik sebagai individu maupun anggota masyarakat.

Pendidikan kewarganegaraan sebagai suatu wahana mencerdaskan bangsa sebagaimana menjadi tujuan nasional di dalam pembukaan UUD 1945 harus mampu membentuk warga negara yang kritis dan reflektif yang merupakan warga negara yang cerdas, bertanggungjawab, memiliki komitmen yang tinggi, dan memiliki kompetensi untuk terus berpartisipasi aktif memajukan kehidupan bermasyarakat, berbangsa dan bernegara. Materi PPKn di semua jenjang kelas mengandung muatan konsep, nilai, moral, dan norma. Semua ini ada dalam materi PPKn SD dan termuat dalam semua standar kompetensi, mulai kelas satu sampai kelas enam. Pengertian konsep adalah semua pengertian yang terdapat dalam pikiran seseorang tentang berbagai hal yang dinyatakan dengan kata-kata. Dalam pembelajaran PPKn SD, konsep perlu dikenalkan pada siswa agar kelak jika memandang masalah dapat runtut, kronologis, dan memiliki konsep yang matang. Dengan demikian, konsep adalah kata yang menunjuk sesuatu. Nilai adalah suatu bobot/kualitas perbuatan kebaikan yang terdapat dalam berbagai hal yang dianggap sebagai barang/sesuatu yang berharga, berguna, dan memiliki manfaat. Nilai adalah kualitas kebaikan yang ada pada sesuatu. Dalam pembelajaran PKn SD, nilai sangat penting untuk ditanamkan sejak dini karena nilai bermanfaat sebagai tuntutan hidup. Contohnya nilai-nilai Pancasila perlu ditanamkan pada anak SD. Moral/moralitas adalah suatu tuntutan perilaku yang baik, yang dimiliki oleh individu sebagai moralitas, yang tercermin dalam pemikiran/konsep, sikap, dan tingah laku. Moral merupakan tuntutan perilaku yang dibawa oleh nilai. Dalam pembelajaran PPKn, moral sangat penting untuk ditanamkan pada siswa usia SD karena proses pembelajaran PPKn SD memang bertujuan untuk membentuk moral anak, yaitu moral yang sesuai dengan nilai falsafah hidupnya. Norma adalah aturan sebagai petunjuk hidup bagi individu dalam masyarakat. Norma merupakan sumber hukum yang menguatkan kedudukan muatan materi dalam PKn yaitu konsep, nilai, moral yang diwujudkan dalam perilaku. Norma dalam masyarakat hendaknya dipatuhi oleh anggota masyarakat, karena norma tersebut mengandung sanksi. Untuk yang melanggar norma tersebut akan mendapat hukuman yang berwujud sanksi misalnya sanksi agama, susila, moral,dll.

Berdasarkan pemaparan tersebut, PKn merupakan suatu mata pelajaran yang memberikan pemahaman dasar tentang pemerintahan, tata cara demokrasi, tentang kepedulian, sikap, pengetahuan politik yang mampu mengambil keputusan politik secara rasional, sehingga dapat mempersiapkan warga negara yang demokratis dan partisipatif melalui suatu pendidikan yang berorientasi pada pengembangan berpikir kritis dan bertindak demokratis.

Pembelajaran PPKn di sekolah dasar dimaksudkan sebagai suatu proses belajar mengajar dalam rangka membantu peserta didik agar dapat belajar dengan baik dan membentuk manusia Indonesia seutuhnya dalam pembentukan karakter bangsa yang 
diharapkan mengarah pada penciptaan suatu masyarakat yang menempatkan demokrasi dalam kehidupan berbangsa dan bernegara yang berlandaskan pada Pancasila, UUD, dan norma yang berlaku di masyarakat yang diselenggarakan selama enam tahun.

Pendidikan kewarganegaraan di sekolah dasar memberikan pelajaran pada siswa untuk memahami dan membiasakan dirinya dalam kehidupan disekolah atau diluar sekolah, karena materi pendidikan kewarganegaraan menekankan pada pengalaman dan pembiasaan dalam kehidupan sehari-hari yang ditunjang oleh pengetahuan dan pengertian sederhana sebagai bekal untuk mengikuti pendidikan berikutnya.

Esensi pembelajaran PPKn bagi anak adalah bahwa secara kodrati maupun sosiokultural dan yuridis formal, keberadaan dan kehidupan manusia selalu membutuhkan nilai, moral, dan norma.

Berdasarkan pemaparan tersebut, hasil belajar PPKn di SD merupakan pencapaian siswa setelah mengikuti kegiatan pembelajaran berupa perubahan-perubahan tingkah laku sebagai hasil dari pengalaman yang berkaitan dengan muatan pelajaran PPKn.

Melalui mata pelajaran PPKn diharapkan peserta didik bukan hanya memiliki pengetahuan yang luas tentang materi pokok PPKn yang meliputi politik, hukum, dan moral (pengetahuan kewarganegaraan), tetapi juga memiliki keterampilan dalam merespon berbagai persoalan politik, hukum, moral, dan terampil menggunakan hak dan kewajibannya di bidang politik, hukum, dan moral (keterampilan kewarganegaraan).

Adapun alasan yang melandasi PPKn perlu diajarkan pada siswa adalah sebagai berikut: 1) sebagai mahluk hidup, manusia bersifat multikodrati dan multifungsi, manusia bersifat multikompleks dan memiliki kodrat ilahi, sosial, budaya, ekonomi dan politik; 2) setiap manusia memiliki sense of yang menunjukkan integritas atau keterkaitan atau kepedulian manusia akan sesuatu; 3) manusia ini unik, hal ini karena potensinya yang multipotensi dan fungsi peran serta kebutuhan atau human desire yang multiperan.

Berdasarkan hasil wawancara dengan wali kelas yang dilakukan di SD Negeri 3 Banjar Jawa Kecamatan Buleleng Kabupaten Buleleng, pada hari selasa dan rabu tanggal 6 dan 7 Februari 2018 pukul 08.00 wita, penggunaan model pembelajaran dan media pembelajaran yang digunakan oleh guru belum maksimal, hal ini akan berdampak pada hasil belajar yang diperoleh siswa. Hal ini dipengaruhi oleh beberapa faktor. Menurut Djamarah (2011:176), "faktor yang mempengaruhi hasil belajar adalah faktor internal dan eksternal". Yang termasuk kedalam faktor internal yaitu faktor fisiologis dan faktor psikologis, sedangkan faktor eksternal yaitu faktor lingkungan dan faktor instrumental. Model pembelajaran sebagai salah satu faktor yang termasuk kedalam faktor eksternal, dapat mempengaruhi hasil belajar siswa. Maka dari itu, diperlukan adanya suatu model pembelajaran yang inovatif. Selain sebagai suatu penyegaran, juga berdampak akan timbulnya motivasi belajar siswa. Apabila motivasi belajar siswa tinggi, maka aktifitas belajar siswa akan meningkat sehingga berpengaruh pada hasil belajar siswa.

Ditinjau dari penemuan tersebut, untuk memperkaya inovasi sekaligus sebagai penyegaran sangatlah baik apabila diterapkan model pembelajaran dengan model lain salah satunya model pembelajaran quantum.

Model Pembelajaran Quantum merupakan pembelajaran yang berlangsung secara meriah dengan segala suasananya. Menurut Bobbi DePorter dan Mike Hernacki (2016 : 14), "Quantum Learning berakar dari upaya Dr. Georgi Lozanov, seorang pendidik berkebangsaan Bulgaria yang bereksperimen dengan apa yang disebut dengan "suggestology" atau "suggestopedia"'. Prinsipnya adalah sugesti dapat dan pasti mempengaruhi hasil situasi belajar, dan setiap detail apapun memberikan sugesti positif maupun negatif. Lebih lanjut, pembelajaran quantum adalah interaksi yang mengubah energi menjadi cahaya. Menurut Trianto (dalam Kosasih, 2013:1) "pembelajaran quantum adalah suatu perencanaan atau suatu pola yang digunakan sebagai pedoman dalam merencanakan pembelajaran di kelas atau pembelajaran dalam tutorial". Menurut De Porter (dalam Kosasih, 2013:75) "pembelajaran quantum adalah interaksi yang mengubah energy menjadi cahaya". Menurut Trianto (dalam Kosasih, 2007:1) "pembelajaran quantum adalah suatu perencanaan 
atau suatu pola yang digunakan sebagai pedoman dalam merencanakan pembelajaran di kelas atau pembelajaran dalam tutorial". Pembelajaran quantum sangat menekankan pada kebermaknaan dan kebermutuan proses pembelajaran. Pembelajaran ini dilaksanakan dengan proses yang benar-benar terencana dengan baik. Pembelajaran quantum merupakan kiat, petunjuk, strategi dan seluruh proses belajar yang dapat mempertajam pemahaman dan daya ingat, serta belajar sebagai suatu proses yang menyenangkan dan bermanfaat. Pembelajaran quantum didasarkan pada anggapan bahwa semua kehidupan merupakan energi yang dapat diubah menjadi cahaya. Maksudnya interaksi-interaksi ini mengubah kemampuan dan bakat alamiah guru dan peserta didik menjadi cahaya yang bermanfaat bagi kemajuan mereka dalam belajar secara efektif dan efisien. Dengan kata lain interaksi-interaksi yang dimaksud mengubah kemampuan dan bakat alamiah peserta didik menjadi cahaya yang akan bermanfaat bagi mereka sendiri dan orang lain. Model pembelajaran quantum merupakan model pembelajaran yang inovatif dan berorientasi pada peserta didik (student centered). Pembelajaran quantum menekankan kegiatan pada pengembangan potensi manusia secara optimal melalui cara-cara yang sangat manusiawi yaitu mudah, menyenangkan dan memberdayakan. Setiap anggota komunitas belajar dikondisikan untuk saling mempercayai dan saling mendukung. Siswa dan guru berlatih dan bekerja sebagai tim guna mencapai kesuksesan bersama. Dalam hal ini, sukses guru adalah sukses peserta didik dan sukses peserta didik berarti sukses guru. Model ini dipandang sebagai model pembelajaran yang ideal, karena menekankan pada kerjasama antara peserta didik dengan guru dalam mencapai tujuan bersama, dan dipandang efektif karena memungkinkan peserta didik dapat belajar secara optimal, yang pada gilirannya diharapkan dapat meningkatkan hasil belajar.

Adapun lima prinsip atau kebenaran tetap yang menjadi tolak ukur disetiap pelaksanaan model pembelajaran Quantum yaitu sebagai berikut. 1) Segalanya berbicara. Segalanya dari lingkungan kelas hingga bahasa tubuh guru bahkan hingga rancangan pembelajaran guru, semuanya mengirim pesan tentang belajar. 2) Segalanya bertujuan. Semua yang terjadi dalam pengubahan guru menjadi tujuan. 3) Pengalaman sebelum memberi nama. Otak kita berkembang pesat dengan adanya rangsangan kompleks, yang akan menggerakkan rasa ingin tahu. Oleh karena itu, proses belajar paling baik terjadi ketika siswa telah mengalami informasi sebelum mereka memperoleh nama-nama untuk apa yang mereka pelajari. 4) Akui setiap usaha. Proses belajar mengandung resiko. Belajar berarti melangkah keluar dari kenyamanan. Pada saat siswa mengambil langkah itu, mereka patut mendapat pengakuan atas kecakapan dan kepercayaan diri mereka. 5) Jika layak dipelajari, maka layak pula dirayakan. Perayaan adalah sarapan pelajar sang juara. Perayaan adalah umpan balik mengenai kemajuan dan meningkatkan asosiasi emosi positif dengan belajar.

DePorter memaparkan bahwa "yang merupakan ciri khusus dan menjadi kerangka rancangan dalam quantum teaching adalah sintaks yang dikenal sebagai TANDUR". Adapun sintaks TANDUR yang dimaksud adalah sebagai berikut. 1) Tumbuhkan. Tumbuhkan minat dengan memuaskan "Apakah Manfaatnya Bagiku" (AMBAK) dan manfaatkan kehidupan pebelajar. 2) Alami. Ciptakan atau datangkan pengalaman umum yang dapat dimengerti oleh semua pelajar. 3) Namai. Sediakan kata kunci, konsep, model, rumus, strategi, sebagai sebuah "masukan". 4) Demonstrasikan. Sediakan kesempatan bagi pelajar untuk "menunjukkan bahwa mereka tahu". 5) Ulangi. Tunjukkan siswa cara-cara mengulang materi dan menegaskan "Aku tahu bahwa aku memang tahu ini". 6) Rayakan. Pengakuan untuk penyelesaian, partisipasi, dan pemerolehan keterampilan dan ilm pengetahuan. Dalam pelaksanaannya pun harus sesuai dengan urutan pelaksanaannya yaitu dimulai dari tumbuhkan, alami, namai, demonstrasikan, ulangi dan rayakan.

Pada pembelajaran quantum yang menjadi tujuan utama adalah siswa. Jadi guru mengupayakan berbagai interaksi dan menyingkirkan hambatan belajar dengan cara yang tepat agar siswa belajar secara mudah dan alami. Quantum learning sebagai salah satu model pembelajaran yang memadukan antara berbagai sugesti positif dan interaksinya dengan lingkungan yang dapat mempengaruhi proses dan hasil belajar seseorang. 
Dengan diterapkannya inovasi pembelajaran berupa model pembelajaran quantum, guru dapat menciptakan suasana belajar yang mengaktifkan siswa secara fisik dan mental, merangsang kreatifitas siswa untuk terus mengembangkan kreatifitasnya baik itu mengenai pengembangan kemampuan imajinasi, daya cipta siswa, serta mampu menciptakan suasana gembira atau menyenangkan sehingga dapat mempengaruhi meningkatnya hasil belajar PPKn.

Untuk mencapai tujuan pembelajaran yang optimal diperlukan keterlibatan seluruh komponen pendidikan termasuk guru, siswa dan model pembelajaran dengan materi pelajaran yang akan disajikan. Dengan kompetensi yang dimiliki, guru mampu memahami bagaimana memilah dan memilih serta mengkiati kesesuaian bahan ajar dengan penerapan pendekatan atau strategi pembelajaran dan media pembelajaran yang akan digunakan sehingga mencapai sasaran atau tujuan pembelajaran yang lebih efektif dan efisien. Sehingga penerapan model pembelajaran quantum diharapkan mampu mengatasi permasalahan yang berkaitan dengan pembelajaran PPKn.

Selain penerapan model pembelajaran quantum yang inovatif, penggunaan media juga sangat perlu diterapkan dalam proses pembelajaran. Secara umum, media merupakan kata jamak dari medium yang berarti perantara atau pengantar. Menurut Rossi dan Breidle (dalam Sanjaya, 2010: 163) mengemukakan bahwa "media pembelajaran adalah seluruh alat dan bahan yang dapat dipakai untuk mencapai tujuan pendidikan seperti radio, televisi, buku, koran, majalah, dan sebagainya". Arsyad, (2014:3) mengatakan bahwa "guru, buku teks, dan lingkungan sekolah merupakan media". Secara lebih khusus, pengertian media dalam proses belajar mengajar cenderung diartikan sebagai alat-alat grafis, photografis, atau elektronis untuk menangkap, memproses, dan menyusun kembali informasi visual atau verbal. Jadi, dari pendapat tersebut dapat disimpulkan bahwa media pembelajaran adalah segala sesuatu yang dapat digunakan untuk menyampaikan pesan atau informasi dalam proses belajar mengajar sehingga dapat merangsang perhatian dan minat siswa dalam belajar. Dilihat dari sifatnya, media dapat dibagi menjadi tiga yaitu media auditif, media visual dan media audio-visual. Media audio-visual merupakan media yang digunakan dalam kegiatan pembelajaran dengan melibatkan pendengaran dan penglihatan sekaligus dalam satu proses atau kegiatan. Pesan dan informasi yang dapat disalurkan melalui media ini dapat berupa pesan verbal dan nonverbal yang mengandalkan baik penglihatan maupun pendengaran. Media audio-visual berupa video merupakan media yang menampilkan gerak, semakin lama semakin popular dalam masyarakat kita.

Dalam penelitian ini, peneliti akan menggunakan media audio-visual berupa video. Video sebagai media audio-visual yang menampilkan gerak, semakin lama semakin popular dalam masyarakat kita. Pesan yang disajikan bisa bersifat fakta (kejadian/peristiwa penting, berita) maupun fiktif, bisa bersifat informatif, edukatif maupun instruksional. Adapun kelebihan penggunaan media audio-visual berupa video yaitu dapat menarik perhatian untuk periode yang singkat dari rangsangan luar lainnya dan dengan alat perekam pita video sejumlah besar penonton dapat memperoleh informasi dari ahli/spesialis.

Selain media audio-visual, media puzzle juga digunakan dalam penelitian ini. Media puzzle adalah alat yang digunakan untuk menyalurkan pesan dengan cara menyambungkan bagian satu dengan yang lainnya sehingga membentuk suatu gambar. Puzzle termasuk salah satu media edukatif berupa gabungan dari beberapa potongan gambar yang dapat membantu mengembangkan kreativitas berpikir anak. Media puzzle dapat melatih kemampuan berpikir logis dengan menyusun gambar sesuai urutan, melatih koordinasi mata dengan tangan, melatih motorik halus dan menstimulasi kerja otak. ketersediaan media puzzle dapat menunjang terselenggaranya proses pengenalan anak secara efektif dan menyenangkan, sehingga siswa dapat mengembangkan potensi yang dimiliki secara optimal.

Model pembelajaran quantum berbantuan media audio-visual dan media puzzle nantinya akan meningkatkan hasil belajar. Peningkatan hasil belajar siswa dari diterapkannya model pembelajaran quantum berbantuan media audio-visual dan media 
puzzle telah dibuktikan oleh penelitian yang dilakukan oleh Nyna Adhitama pada tahun 2015 yang berjudul Implementasi Quantum Learning Berbantuan Mind Mapping Worksheet untuk Mengukur Kemampuan Komunikasi dan Hasil Belajar Peserta Didik. Dalam penelitiannya model pembelajaran quantum berpengaruh terhadap tingkat kemampuan komunikasi.

Berdasarkan paparan latar belakang tersebut, dilakukan penelitian melalui penerapan model pembelajaran quantum berbantuan media audio-visual dan puzzle. Tujuannya untuk meningkatan hasil belajar PPKn melalui penerapan model pembelajaran quantum berbantuan media audio-visual dan puzzle siswa kelas V SD Negeri 3 Banjar Jawa.

\section{Metode}

Jenis penelitian yang dilaksanakan adalah Penelitian TIndakan Kelas (PTK). Penelitian Tindakan Kelas diartikan sebagai proses pengkajian masalah pembelajaran di dalam kelas melalui refleksi diri dalam upaya untuk memecahkan masalah tersebut dengan cara melakukan berbagai tindakan yang terencana dalam situasi nyata serta menganalisis setiap pengaruh dari perlakuan tersebut. Lokasi penelitian ini dilaksanakan di SD Negeri 3 Banjar Jawa semester II tahun ajaran 2017/2018. Subjek penelitian adalah siswa kelas VC SD Negeri 3 Banjar Jawa tahun ajaran 2017/2018 sebanyak 32 orang yakni 13 orang siswa lakilaki dan 19 orang siswa perempuan.

Penelitian ini dilaksanakan dalam 2 siklus. Dalam satu siklus, dilaksanakan 3 kali pertemuan yakni 2 kali pertemuan untuk pelaksanaan pembelajaran dan satu pertemuan untuk pelaksanaan tes akhir siklus. Setiap siklus terdiri dari empat tahap yaitu perencanaan, pelaksanaan, observasi atau evaluasi, dan refleksi.

Pada tahap perencanaan, kegiatan yang dilakukan adalah: 1) Menganalisis kurikulum untuk mengetahui kompetensi dasar dan indikator pada muatan PPKn yang akan disampaikan kepada siswa.2) Membuat rencana pelaksanaan pembelajaran (RPP) yang menerapkan model pembelajaran quantum berbantuan media audio-visual dan media puzzle yang disesuaikan dengan pokok bahasan, menyiapkan bahan ajar serta menyiapkan lembar kerja peserta didik (LKPD). 3) Membuat media pembelajaran berupa media audiovisual dan media puzzle untuk mendukung pembelajaran. 4) Membuat instrumen penelitian tes hasil belajar yang berbentuk tes pilihan ganda sebanyak 30 butir soal untuk tiap akhir siklus.

Pada tahap tindakan, dilaksanakan pembelajaran berdasarkan rencana pembelajaran yang telah disusun. Pada tahap perencanaan dengan menerapkan model pembelajaran quantum. Selama pelaksanaan tindakan penelitian, siswa difasilitasi untuk aktif mengikuti pembelajaran sesuai dengan skenario atau langkah-langkah/ sintak model pembelajaran quantum yaitu sintaks tandur (tanamkan, alami, namai, demostrasi, ulangi dan rayakan) berbantuan media audio-visual dan media puzzle.

Pada tahap observasi, kegiatan yang dilaksanakan adalah mengamati segala fenomena yang terjadi selama proses tindakan serta kendala-kendala yang dialami dalam penerapan model pembelajaran quantum berbantuan media audio-visual dan media puzzle. Selain itu dilakukan juga kegiatan dokumentasi terhadap hal-hal penting yang terjadi selama proses pembelajaran. Kendala-kendala atau kejadian penting saat berlangsungnya proses pembelajaran juga dicatat. Pada akhir siklus, dilakukan tes tertulis berbentuk pilihan ganda untuk melihat peningkatan kemampuan siswa berkaiatan dengan materi yang telah disajikan melalui penerapan model pembelajaran quantum.

Hasil yang didapat dalam tahap observasi dikumpulkan serta dianalisis. Kegiatan yang dilakukan pada tahap ini adalah menganalisis, memaknai, menjelaskan, dan menyimpulkan data yang diperoleh dari hasil observasi, catatan, dan hasil tes yang telah diberikan kepada siswa. Hasil dari kegiatan ini berupa informasi yang digunakan sebagai dasar untuk merancang kegiatan yang dilakukan pada siklus berikutnya. Refleksi dilakukan dengan melihat hambatan-hambatan yang dialami dalam pelaksanaan tindakan pada setiap siklus dan faktor penyebab hambatan tersebut, selanjutnya mencari dan menetapkan beberapa 
alternatif tindakan baru yang diduga lebih efektif untuk meningkatkan motivasi belajar dan hasil belajar PPKn.

Metode pengumpulan data dalam penelitian ini adalah dengan metode tes. "Metode tes adalah cara memperoleh data yang berbentuk suatu tugas yang harus dikerjakan oleh seseorang atau sekelompok orang yang dites dan dari tes dapat menghasilkan suatu skor" (Agung, 2014:3). Metode tes digunakan untuk mengukur peningkatan hasil belajar PPKn siswa. Instrumen pengumpulan data menggunakan soal objektif tipe pilihan ganda yang terdiri dari 30 soal dengan skala interval/skor.

Setelah data dalam penelitian ini terkumpul maka selanjutnya dilakukan analisis data. Dalam menganalisis data ini digunakan metode analisis statistik deskriptif dan metode analisis deskriptif kuantitatif. Agung (2014:142) menyatakan bahwa analisis statistik deskriptif adalah cara pengolahan data yang dilakukan dengan jalan menerapkan rumus-rumus statistik deskriptif seperti distributif frekuensi, grafik, angka rata-rata (Mean), median (Median), dan modus (Modus) untuk menggambarkan keadaan objek/variabel sehingga diperoleh kesimpulan umum. Sedangkan analisis deskriftif kuantitatif adalah suatu cara pengolahan data yang dilakukan dengan jalan menyusun secara sistematis dalam bentuk angka-angka dan atau presentase mengenai suatu objek yang diteliti sehingga diperoleh kesimpulan umum.

Pada analisis data ini dicari persentase hasil belajar PPKn siswa dan selanjutnya dibandingkan dengan indikator keberhasilan yang ditetapkan. Indikator keberhasilan merupakan acuan atau tolak ukur untuk melihat keberhasilan tindakan yang dilakukan. Indikator keberhasilan yang diterapkan sebagai kriteria keberhasilan dalam penelitian ini yaitu sebagai berikut. 1) Jika rata-rata persen hasil belajar siswa minimal $80 \%$ atau berada pada kategori tinggi (80-89). 2) Jika kriteria peningkatan (Gn) hasil belajar siswa berada pada kategori sedang $(0,30-0,69)$.

\section{Hasil dan Pembahasan}

Pelaksanaan pembelajaran selama penelitian menggunakan model pembelajaran quantum berbantuan media audio-visual dan media puzzle pada muatan PPKn siswa kelas V C SD Negeri 3 Banjar Jawa tahun ajaran 2017/2018 telah berlangsung sesuai dengan rencana pembelajaran yang telah disusun. Setiap siklus terdiri dari tiga kali pertemuan. Pertemuan pertama dan kedua merupakan pembelajaran dengan menerapkan model pembelajaran quantum berbantuan media audio-visual dan media puzzle, sedangkan pertemuan ketiga merupakan tes akhir siklus berupa soal pilihan ganda. Data yang dikumpulkan dalam penelitian ini adalah data hasil belajar PPKn.

Pelaksanaan tindakan pada siklus I dilaksanakan terhadap 32 siswa kelas IV SD Negeri 3 Banjar Jawa dengan sasaran mendapatkan data hasil belajar PPKn. Pertemuan pertama dilaksanakan pada hari Kamis 29 Maret 2018. Pertemuan dua dilaksanakan pada Sabtu, 31 Maret 2018, dan pertemuan ketiga yaitu pelaksanaan tes akhir siklus dilaksanakan pada hari Rabu, 4 April 2018. Hasil penelitian siklus I menunjukkan persentase rata-rata hasil belajar PPKn secara klasikal yaitu 76,6 dengan nilai perolehan 2.450. Kemudian nilai rata-rata tersebut dihitung ke dalam $\mathrm{M} \%$ untuk mengetahui persentase ratarata hasil belajar siswa. Presentase hasil belajar PPKn siswa kelas V C adalah 76,6\%, dan apabila dikonversikan ke dalam PAP skala lima untuk kriteria hasil belajar PPKn maka hasil belajar PPKn untuk siklus I tergolong sedang. Dari hasil pengamatan dan temuan selama pemberian tindakan pada siklus I terdapat beberapa masalah yang menyebabkan hasil belajar PPKn belum mencapai target yang diharapkan. Masalah-masalah tersebut dapat dikemukakan sebagai berikut. 1) Siswa belum terbiasa dengan model pembelajaran yang digunakan, sehingga dalam pembelajaran belum terlaksana secara efektif. Hal ini disebabkan karena model yang digunakan merupakan hal baru bagi siswa dan berbeda dengan pembelajaran sebelumnya. 2)Siswa masih belum optimal dalam melakukan pengamatan terhadap media video. Ketika video ditayangkan, siswa asyik berbicara dengan teman kelompoknya. 3) Dalam diskusi kelompok saat menyelesaikan puzzle dalam LKS 
hanya beberapa siswa yang mengerjakan tugas, sedangkan siswa yang lainnya hanya diam saja. Mengacu pada kekurangan yang dihadapi pada siklus I, dilakukan diskusi dengan guru untuk merancang perbaikan tindakan untuk selanjutnya diterapkan pada siklus II. Berdasarkan hasil diskusi bersama guru kelas, maka pada siklus II akan dilakukan langkahlangkah perbaikan. Adapun langkah-langkah rencana siklus II adalah sebagai berikut. 1) Sebelum melaksanakan tindakan pada siklus II, siswa diberikan penjelasan tentang langkah kegiatan yang akan diterapkan agar siswa memiliki kesiapan dalam mengikuti pembelajaran dengan penerapan model pembelajaran quantum berbantuan media audio-visual dan puzzle. 2) Memberikan bimbingan atau arahan kepada siswa untuk memperhatikan media yang ditampilkan guru. 3) Saat melakukan diskusi, guru harus mengawasi serta membimbing siswa sehingga semua siswa ikut terlibat dalam kegiatan diskusi.

Setelah melakukan refleksi pada siklus I diperoleh hasil belajar siswa dan masalah yang terjadi. Beranjak dari hasil penelitian tersebut, maka diadakan perbaikan pembelajaran pada siklus II.

Pelaksanaan tindakan pada siklus II dilaksanakan mulai tanggal 5-7 April 2018. Hasil penelitian siklus I menunjukkan persentase rata-rata hasil belajar PPKn secara klasikal yaitu 88,2 dengan nilai perolehan 2.823. Kemudian nilai rata-rata tersebut dihitung ke dalam M\% untuk mengetahui persentase rata-rata hasil belajar siswa. Presentase hasil belajar PPKn siswa kelas VC adalah $88,2 \%$, dan apabila dikonversikan ke dalam PAP skala lima untuk kriteria hasil belajar PPKn maka hasil belajar PPKn untuk siklus II tergolong tinggi. Selanjutnya, untuk mengetahui tinggi rendahnya atau keberartian peningkatan tindakan dalam PTK digunakan rumus Gn skor. Peningkatan hasil belajar berdasarkan rumus Gn skor sebesar 0,49 dan apabila dikonversikan ke dalam tabel kriteria peningkatan hasil maka peningkatan hasil belajar berada pada kategori sedang. Setelah dilaksanakan tindakan pada siklus II, hasil yang dicapai siswa mengalami peningkatan. Masalah dan kendala yang dihadapi pada siklus I dapat diatasi pada siklus II. Terbukti dengan adanya peningkatan hasil belajar PPKn siswa. Dari analisis data hasil belajar PPKn, diperoleh rata-rata hasil belajar siswa yaitu 88,2 dengan rata-rata persen sebesar $88,2 \%$. Bila dikonversikan ke tabel pedoman konversi PAP skala lima tentang tingkatan hasil belajar PPKn siswa berada pada persentase 80-89 dengan kategori tinggi. Hal ini menunjukkan bahwa pembelajaran dengan menerapkan model pembelajaran quantum berbantuan media audio-visual dan puzzle sudah berlangsung dengan baik.

Setelah dilaksanakan siklus II, kembali diadakan refleksi bersama guru kelas V C. Pada refleksi siklus II ternyata kelemahan-kelemahan yang terjadi pada siklus I dapat diatasi pada siklus II. Adapun yang dijadikan refleksi pada siklus II sebagai berikut. 1) Siswa mulai terbiasa mengikuti proses pembelajaran dengan menggunakan model pembelajaran quantum berbantuan media audio-visual dan puzzle. 2) Siswa sudah cukup optimal dalam melakukan pengamatan terhadap media video. Saat media video ditayangkan, siswa memperhatikan dengan sangat seksama. 3) Kerjasama yang terbentuk antar kelompok sangat baik karena siswa yang lebih bisa wajib memberitahu teman yang belum mengerti dalam satu kelompok.

Pada refleksi siklus II juga dilakukan refleksi akhir dengan tujuan untuk memperoleh gambaran umum mengenai hasil belajar PPKn dalam penelitian ini. Persentase rata-rata hasil belajar PPKn secara klasikal pada siklus I mengalami peningkatan dari $76,6 \%$ menjadi $88,2 \%$ pada siklus II.

Berdasarkan hasil tindakan siklus II, dapat diketahui indikator keberhasilan sudah tercapai. Hal ini dibuktikan dengan telah mencapai target yang diinginkan yaitu rata-rata hasil belajar siswa berada pada kategori tinggi (80-89) dan kriteria peningkatan (Gn) hasil belajar siswa berada pada kategori sedang $(0,30-0,69)$.

Untuk lebih jelasnya, ringkasan peningkatan hasil belajar PPKn pada penelitian ini dapat diamati pada tabel 1 tentang rekapitulasi hasil penelitian di bawah ini. 
Tabel 1. Rekapitulasi Hasil Penelitian

\begin{tabular}{cccccc}
\hline \multicolumn{2}{c}{ Objek Penelitian } & Siklus I & Siklus II & Besar Peningkatan & Gn Skor \\
\hline Hasil Belajar & Rata-rata & 76,6 & 8,2 & 11,60 & 0,49 \\
PPKn & M\% & $76,6 \%$ & $88,2 \%$ & $11,60 \%$ & Sedang \\
\hline
\end{tabular}

Dari Tabel 1 tersebut, dapat dilihat adanya peningkatan hasil belajar PPKn dari siklus I ke siklus II. Peningkatan ini tidak terlepas dari penerapan model quantum berbantuan media audio-visual dan puzzle yang dilaksanakan secara optimal. Model pembelajaran quantum merupakan model pembelajaran yang inovatif dan berorientasi pada peserta didik (student centered). Pembelajaran quantum menekankan kegiatan pada pengembangan potensi manusia secara optimal melalui cara-cara yang sangat manusiawi yaitu mudah, menyenangkan dan memberdayakan. Setiap anggota komunitas belajar dikondisikan untuk saling mempercayai dan saling mendukung. Siswa dan guru berlatih dan bekerja sebagai tim guna mencapai kesuksesan bersama. Model ini dipandang sebagai model pembelajaran yang ideal, karena menekankan pada kerjasama antara peserta didik dengan guru dalam mencapai tujuan bersama, dan dipandang efektif karena memungkinkan peserta didik dapat belajar secara optimal. Selain itu penggunaan media audio-visual dan puzzle sangat mempengaruhi peningkatan hasil belajar tersebut. Media audio-visual berupa video dapat melengkapi pengalaman-pengalaman dasar siswa ketika siswa berdiskusi, membaca dan praktik; mendorong dan meningkatkan motivasi siswa serta menanamkan sikap dan segi afektif yang erat kaitannya dengan nilai moral Pancasila; video mengandung nilai-nilai positif yang dapat mengundang pemikiran dan pembahasan dalam kelompok siswa.

Hasil penelitian menunjukkan hasil belajar PPKn pada siklus I belum mencapai kriteria keberhasilan yaitu masih ada beberapa siswa secara individu memiliki hasil belajar PPKn pada kategori rendah. Hal ini disebabkan karena siswa tidak menyimak proses pembelajaran, hasil belajar PPKn belum mencapai kriteria keberhasilan yang ditentukan dalam penelitian ini. Maka dari itu segala upaya dirancang untuk menanggulangi kelemahan pada siklus I dan selanjutnya akan dilaksanakan pada siklus II. Pada siklus II, segala yang dirancang dan diupayakan berjalan dengan lancar sehingga pada siklus II terjadi peningkatan motivasi dan hasil belajar PPKn.

Berdasarkan upaya perbaikan pembelajaran dan pelaksanaan tindakan pada siklus I, maka pada pelaksanaan siklus II telah tampak adanya peningkatan rata-rata hasil belajar PPKn siswa. Pada siklus I rata-rata hasil belajar PPKn siswa sebesar 76,6 berada pada kategori sedang dan mengalami peningkatan pada siklus II menjadi 88,2 dengan kategori tinggi. Peningkatan yang terjadi jika dihitung menggunakan rumus $\mathrm{Gn}$ skor yaitu sebesar 0,49 yang jika dikonversikan pada tabel kriteria peningkatan hasil belajar berada pada kategori sedang $(0,30-0,69)$.

Hal ini sejalan dengan penelitian yang dilakukan oleh Tantri (2013) dengan judul Pengaruh Model Pembelajaran Quantum Teaching Bermuatan Permainan Puzzle Terhadap Hasil Belajar IPA Kelas IV SD Gugus I Kecamatan Nusa Penida. Dalam penelitiannya menunjukkan bahwa siswa yang dibelajarkan dengan model pembelajaran quantum berbantuan puzzle lebih baik dari siswa yang dibelajarkan dengan pembelajaran konvensional ( $\left.t_{\text {hit }}>t_{\text {tab }}\right)$.

Berdasarkan pembahasan tersebut, penelitian ini dapat dikatakan berhasil, karena semua kriteria yang ditetapkan telah terpenuhi. Jadi, dapat dinyatakan bahwa penerapan model pembelajaran quantum berbantuan media audio-visual dan puzzle dapat meningkatkan hasil belajar PPKn siswa kelas V C semester II tahun ajaran 2017/2018 di SD Negeri 3 Banjar Jawa. 


\section{Simpulan dan Saran}

Berdasarkan hasil penelitian dan pembahasan yang telah diuraikan, dapat disimpulkan bahwa penerapan model pembelajaran quantum berbantuan media audio-visual dan puzzle dapat meningkatkan dapat meningkatkan hasil belajar PPKn siswa kelas V C semester II tahun ajaran 2017/2018 di SD Negeri 3 Banjar Jawa.

Hal ini dapat dilihat dari meningkatnya hasil belajar PPKn siswa. Pada siklus I rata-rata hasil belajar PPKn siswa sebesar 76,6 dengan M\% sebesar 76,6\% berada pada kategori sedang dan berada pada interval $65-79$ dengan kategori sedang. Sedangkan pada siklus II diperoleh rata-rata hasil belajar PPKn siswa yaitu 88,2 dengan M\% sebesar $88,2 \%$ dan berada pada interval 80 - 89 dengan kategori tinggi. Peningkatan yang terjadi jika dihitung menggunakan rumus $\mathrm{Gn}$ skor yaitu sebesar 0,49 yang jika dikonversikan pada tabel kriteria peningkatan hasil belajar berada pada kategori sedang $(0,30-0,69)$.

Berdasarkan simpulan tersebut ada beberapa hal yang sebaiknya dilakukan sekolah dalam meningkatkan mutu pendidikan yaitu guru diharapkan agar dapat mempertimbangkan penerapan model pembelajaran quantum berbantuan media audio-visual dan puzzle ini sebagai salah satu alternatif pilihan model pembelajaran dalam pembelajaran PPKn guna meningkatkan hasil belajar PPKn yang dicapai siswa. Selain itu, disarankan kepada kepala sekolah agar hasil penelitian ini dapat dijadikan dasar untuk membimbing dan mengarahkan guru dalam mengelola kegiatan pembelajaran sehingga pelaksanaan kegiatan pembelajaran menjadi lebih efektif. Dan disarankan kepada peneliti lain, agar penelitian ini dapat digunakan sebagai salah satu referensi dalam melakukan penelitian serta hasil penelitian ini dapat memberikan suatu konsep dan fakta baru yang bisa dijadikan pedoman dalam perancangan perencanaan pembelajaran maupun pedoman dalam perancangan penelitian selanjutnya.

\section{Daftar Rujukan}

Agung, A.A. G. 2014. Metodologi Penelitian Pendidikan. Singaraja: Fakultas Ilmu Pendidikan Institut Keguruan dan Keilmuan Negeri Singaraja

Daud, Y Erni. 2013. Meningkatkan Kemampuan Dalam Menentukan Pikiran Pokok Melalui Model Pembelajaran CIRC pada Siswa Kelas IV SDN 25 Limboto, (Skripsi) Gorontalo: Universitas Negeri Gorontalo.

DePorter, B \& Mike H. 2016. Quantum Learning: Membiasakan Belajar Nyaman dan Menyenangkan. Bandung: Kaifa

Djamarah, S. 2011. Psikologi Belajar. Jakarta: PT Rineka Cipta

Indah, Wilis. 2017. Pengaruh Model Pembelajaran Kooperatif Tipe CIRC (Cooperative Integrated Reading And Composition) Terhadap Kemampuan Menemukan Kalimat Utama Dalam Paragraf Pada Siswa Kelas IV SDN Blimbing Dan Kalirong 2. SimkiPedagogia Vol. 01 No. 02 Tahun 2017.

Kosasih, N. 2013. Pembelajaran Quantum dan Optimalisasi Kecerdasan. Bandung: Alfabeta

Nyna, A, Parmin \& Sudarmin. 2015. "Implementasi Quantum Learning Berbantuan Mind Mapping Worksheet untuk Mengukur Kemampuan Komunikasi dan Hasil Belajar Peserta Didik". Jurnal Pendidikan MIPA Pascasarjana UNNES, Volume 1 No 3 Tahun 2015 
Rahayu. Nurhayati, dkk. 2013. Penerapan Model Pembelajaran Kooperatif Tipe Cooperative Integrated Reading And Composition (CIRC) dalam Upaya Meningkatkan Kemampuan Pemecahan Masalah Matematika Siswa. Jurnal Analisa 1 (1) (2013).

Sanjaya, W. 2010. Strategi Pembelajaran Berorientasi Standar Proses Pendidikan. Jakarta: Kencana

Solikah, Siti, Dkk. 2014. Penerapan Model Pembelajaran Cooperativeintegrated Reading And Composition(CIRC) Dilengkapimedia Handoutuntuk Meningkatkan Hasil Belajar Dan Minat Siswa Padapokokbahasanminyak Bumikelas X.7 SMA Negeri 1 Sukoharjo. Urnal Pendidikan Kimia (JPK), Vol. 3 No. 3 Tahun 2014.

Sudaryanti. 2013. Penerapan Model Pembelajaran Cooperative Integarted Reading and Composition (CIRC) untuk Meningkatkan Motivasi dan Hasil Belajar Matematika Siswa Kelas VIII SMP Negeri 3 Bagor pada Materi Faktorisasi Bentuk Aljabar Tahun Pelajaran 2013/2104. Skripsi PGSD FKIP UN PGRI Kediri, Kediri.

Susanto, Ahmad. 2014. Teori Belajar dan Pembelajaran di Sekolah Dasar. Jakarta: Kencana.

Sutarno, Heri, Dkk. 2010. Penerapan Model Pembelajaran Cooperative Integrated Reading And Composition (CIRC) Berbasis Komputer Untuk Meningkatkan Hasil Belajar Siswa Pada Pembelajaran TIK. Jurnal Pendidikan Teknologi Informasi Dan Komunikasi (Ptik). Vol. 3 No.1 / Juni 2010.

Wahyu Hartono. 2011. Penerapan Model Pembelajaran Kooperatif tipe CIRC (Coopertaive Integrated Reading and Composition) Melalui Strategi Kartu Soal untuk Meningkatan Kemampuan Pemecahan Masalah Materi Perbandingan Kelas VII SMP Negeri 3 Kediri tahun ajaran 2011/2012 Skripsi PGSD FKIP UN PGRI Kediri. Jurusan Pendidikan Bahasa Dan Sastra Indonesia FKIP Universitas Maritim Raja Ali Haji Tanjungpinang. Tersedia: https://jurnal.umroh.ac.id.

Yudasmini. Ni Made, dkk. 2015. Pengaruh Model Pembelajaran CIRC (Cooperative Integrated Reading And Composition) Terhadap Minat Baca Dan Kemampuan Memahami Bacaan Pada Siswa Kelas VI Di Sekolah Dasar Gugus Buruan. eJournal Program Pascasarjana Universitas Pendidikan Ganesha. Volume 5, No 1 Tahun 2015. 